\title{
対流・放射連成解析と遺伝的アルゴリズム $(\mathrm{GA})$ を用いた屋外温熱環境 の最適設計手法に関する研究 \\ 屋外温熱環境設計のための樹木の最適配置
}

\section{STUDY ON OPTIMUM DESIGN METHOD FOR PLEASANT OUTDOOR THERMAL ENVIRONMENT USING GENETIC ALGORITHM (GA) AND COUPLED SIMULATION OF CONVECTION, RADIATION AND CONDUCTION}

Optimum arrangement of trees for design of pleasant outdoor thermal environment

陳 宏*，大 岡 龍 三**，加藤 信 介***

Hong CHEN, Ryozo OOKA and Shinsuke KATO

\begin{abstract}
A lot of researches have been recently conducted on tree planting in order to improve outdoor thermal environment in summer. In this paper, the optimum design method with Genetic Algorithm (GA) about optimum arrangement of the trees for comfortable outdoor thermal environment is examined with the coupled simulation of convection, radiation and conduction. In this research, in order to clarify the effect of the different target area (all open space or pedestrian road) for optimization, the two cases which are different in target area are examined. As a result, the optimum arrangements of the trees are given using GA and simulation for the two cases.
\end{abstract}

Keywords: GA, Tree, Optimum Arrangement, Outdoor Thermal Environment 遺伝的アルゴリズム, 樹木, 最適配置, 屋外温熱環境

\section{1. 研究の背景と目的}

近年、都市化の進行に伴うヒートアイランド現象が進行し、 都市の屋外温熱環境が悪化してきた。この劣悪な夏季の屋外温熱 環境を改善するために、都市・建築計画と環境工学分野において 多くの研究が行われている。このような背景から、近年緑地と樹 木の配置による潜熱蒸発の促進、及び日射の遮蔽が注目されてい る。例えば、荻島らは、街路樹の放射温度分布を実測し、街路樹 の暑熱緩和効果の数值解析を検討した文 ${ }^{12)}$ 。また、吉田らは、日 射遮蔽効果、風速低減効果、蒸散効果等を総合的に組み込んだ 3 次元樹木モデルを提案し、街路樹の影響を考慮した市街地におけ る屋外温熱環境の数值解析を行った文3)。しかし、以上の研究では 樹木の環境形成効果の評価技術の開発が主であり、樹木を用いた 屋外温熱環境の設計手法の開発・提案にまで十分に至っていると は言い難い。

なお、植樹による快適な屋外温熱環境を設計するためには、 適正な樹木配置が非常に重要な要因となるが、実際の植樹は視覚 的意味合いから経験的になされることが多い。屋外温熱環境に限 らず何かを設計するためには、設計目標を達成することが肝要で ある。また、設計者にとっては、より良い、より効率的な「最適
設計」の手法を確立することが期待されている。しかしそれら経 験的なデザインが実際に「最適」であるかどうかを確認するため には、考えられるデザインをすべて検討（全探查）する必要があ るが、この方法では検討事数が膨大となり、実際的ではない。こ のような問題に対して、建築においても棈造分野や計画分野にお いては比較的早い段階で設計目標となる評価関数值を最大化させ る最適設計手法の研究が行われてきた文4)5(6)。最近では環境分野に おいても室内空調設計を対象に最適設計の研究が進められている 文7。屋外温熱環境設計においても同様のアプローチが可能である。 尚、夏季の暑熱環境の緩和に対する要請が強い現在、樹木の温熱 環境緩和効果に関する設計が確立されれば、多くの屋外環境設計 に今後利用されるものと期待される。しかしながら、今まで、樹 木の最適化が工学的問題として取り扱われることがなかったとい う原因の 1 つはその工学的設計手法が確立されていないというこ とが考えられる。本研究では屋外設計手法の研究の第 1 段階とし て、樹木の温熱環境緩和効果に関わる最適配置設計手法の提案を 行った。今後は他の要因も組み込んだ多目的最適設計手法の検討 を行っていきたいと考えている。

本研究では屋外空間の温熱快適性に着目し、良好な屋外温
* 東京大学大学院工学系研究科 大学院生

** 東京大学生産技術研究所 助教授・博士 (工学)

*** 東京大学生産技術研究所 教授.工博
Graduate Student, University of Tokyo, M. Eng.

Assoc. Prof., Institute of Industrial Science, University of Tokyo, Ph. D.

Prof., Institute of Industrial Science, University of Tokyo, Dr. Eng. 


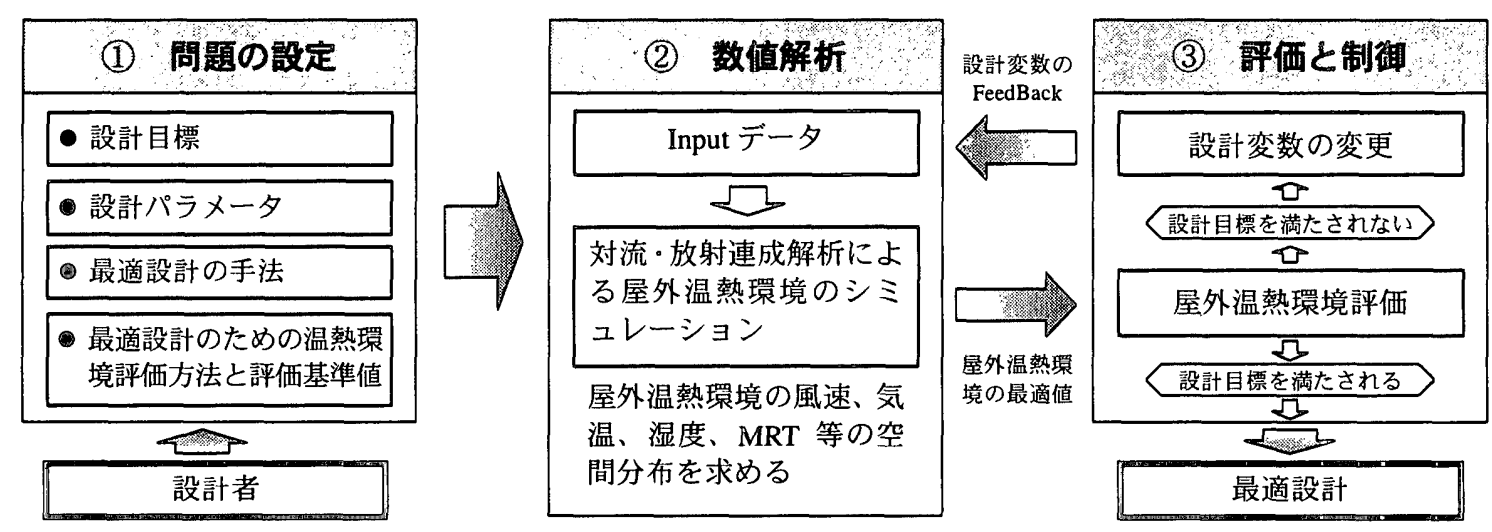

図 1 最適設計システムの構成

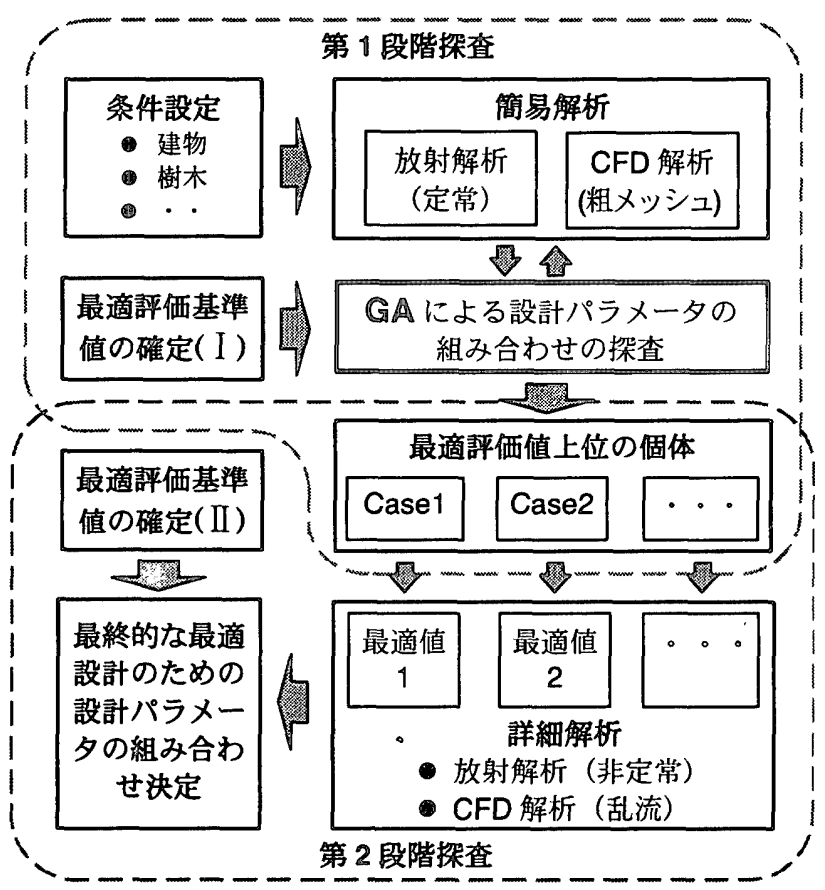

図 22 段階最適設計手法

熱環境を実現するための樹木の最適配置について、放射・対流 連成シミュレーションを援用した最適設計手法の検討を行う。 尚、最適解の探查については、遺伝的アルゴリズム (GA: Genetic Algorithm）文7)を利用する。

\section{2 最適設計システム}

\section{1 最適設計システムの構成}

図 1 に本研究で用いた対流・放射連成解析と GA を用いた屋 外温熱環境の最適設計システムの構成を示す。この最適設計シス テムは、(1)設計者により最適化問題を設定する部分、(2)対流・放 射連成解析により屋外温熱環境を解析する部分、(3)GA により屋 外温熱環境の評価と最適探查過程の制御の部分等 3 つ部分により 構成される。ここで、(1)の部分において、最適設計に関する設計 目標と設計要素を決定し、最適設計手法、最適設計ための屋外温 熱環境の数量化評価方法と最適解の候補を選ぶための基準值も決 定する。(2)の部分において、解析対象における風速、気温、湿度、
MRT の空間分布を算出し、屋外温熱噮境の最適評価値（本研究で は SET*) の空間分布を求める。(3)の部分において、(1)の部分で 決めた最適解の候補を選ぶための基準值を用いて(2)の部分で算出 される屋外温熱環境の洋価值が適合するかどうかを検討する。こ の時、屋外温熱罟境が設計目標を満たさない場合、設計変数の組 み合わせを変更し、(2)の部分へフィードバックすることにより最 適探査を進める。また、屋外温熱環境の評価值が設計目標を満た す場合、(2)の部分へフィードバックを終了する。この時の設計パ ラメータの設定值が最適值となる。

\subsection{2 段階型最適設計手法}

GA を利用した探查について全て詳細な放射・対流連成解析に より検討を行うと計算負荷が膨大となり、実用設計には適さない。 そこで本研究では比較的な粗な計算で上位個体を抽出する第 1 段 階探查とその上位個体群から詳細な解析を用いて最適個体を選ぶ 第 2 段階探査に分ける 2 段階型最適設計手法文》を利用する。図 2 に解析手順を示す。

(1) 第 1 段階探查 : 放射解析は定常解析、CFD 解析は粗メッシ ユの解析で行った。全て解候補のうちに、最適評価値が予 め設定した最適候補基準値を越えるものを第 2 段階の最適 探査の候補とする。

(2) 第 2 段階探查：上記の第 2 段階最適探査の候補に対して、 詳細な放射・対流・湿気輸送連成解析を行った。各個体に ついて気温、風速、相対湿度の空間分布を算出し、最適評 価值を求める。この段階では、放射・伝導解析は非定常解 析、CFD 解析は細メッシュの乱流解析である。

(3) 第 2 段階で解析された設計パラメータの組み合わせの内、 最適評価値（適合度）最も高い個体を最適設計とする。

\section{3。最適化問題の設:定}

\section{1 設計目標}

本研究は夏季における樹木の最適配置による屋外温熱環境の 最適化を設計目標とする。具体的には後述する最適化評価関数(こ こでは SET*の低下) の空間分布の值の屋外空間における空間積 分を最大化するような樹木の最適配置の探查を行う。

\section{2 解析対象}

図 3 に街区モデルをを示す。同一形状の建物モデルで構成され る街区を想定する。解析の日時は東京の 7 月 23 日午後 3 時を対象 


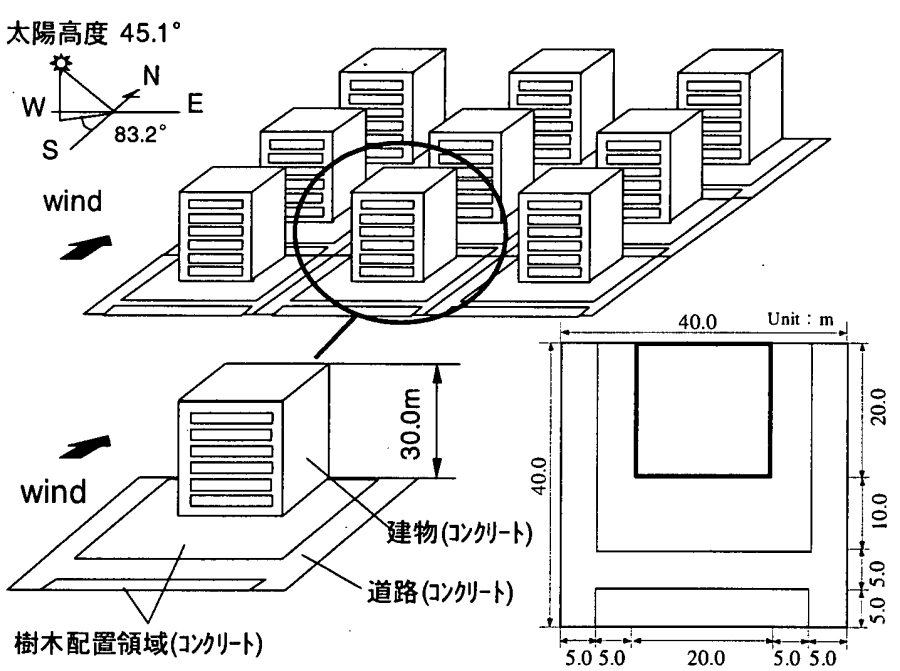

図 3 解析対象

とする。太陽高度は $45.1^{\circ}$ 、風向は南、風速は高さ $74.6 \mathrm{~m}$ におい て $3.0 \mathrm{~m} / \mathrm{s}$ 、外気温、相対湿度はそれぞれ $31.6^{\circ} \mathrm{C} 、 58 \%$ と想定した。 また、本モデルにおける樹木の本数は 8 本であると固定し、その 高さは $7 \mathrm{~m}$ 、樹冠径 $5 \mathrm{~m}$ とする。本研究で利用する樹木モデルは吉 田らが開発したものである文)。

\section{3 設計パラメータ}

本研究では、解析領域における樹木の位置を設計パラメータ とする。具体的には、それぞれの樹木が後述する解析領域におけ る全ての 26 箩所の樹木配置できるメッシュのうち、実際に樹木を 配置するメッシュの番号を本研究の設計パラメータとした。

\section{4 評価関数}

最適の数量化評価は、基本ケースとする樹木が配置されない ケースにおける SET*文9)の空間分布に対して、樹木を配置した場 合の SET*の変化量、すなわち、樹木の配置による屋外温熱環境 の改善程度により評価する。

具体的には、まず、基本ケースについて、放射・対流連成解 析を行い、SET*の空間分布を求める。次に、樹木を配置した場合 の放射・対流連成解析により SET*の空間分布を算出し、下記の 式で評価関数（適合度）を計算する：

$$
F_{\text {total }}=\sum\left\{B_{j}-D_{j}\right\}
$$

$F_{\text {total }}$ ：最適程度を判断するための評価値（適合度）

$B_{j} \quad:$ 樹木がない場合の $j$ ポイントの SET*の値

$D j \quad$ : 樹木を配置した場合の $j$ ポイントの SET*の值

本研究では、最適化評価関数の空間分布の值の屋外空間にお ける空間積分值を最大化するような樹木の最適配置を設計目標と する。そのため、評価関数が高い最適解の候補が高適合度の個体 となる。

\subsection{GA による最適探查と染色体の記述方法}

遺伝的アルゴリズム $(\mathrm{GA})$ は最適化問題を生物の進化の過程 に模做した方法によって解く。ここでは、個体と呼ばれる最適の 解候補は一つの生物とみなす。生物の進化と同じように、個体の 情報は「染色体」（chromosome）と呼ぶ記号列により記述し、個 体と染色体を一対一に対応づけしておく。GA は各個体の染色体

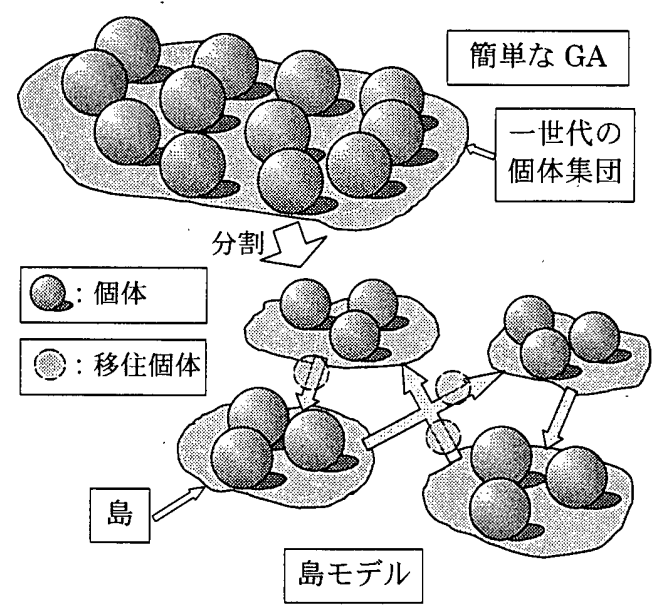

図 4 島モデルの概念

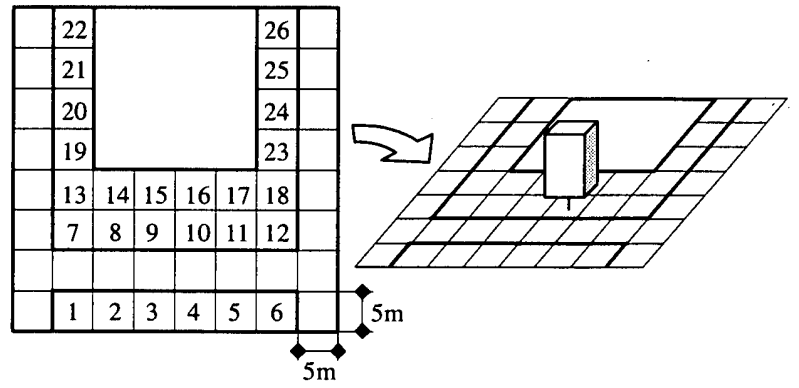

メッシュ番号の割り付け

\begin{tabular}{|c|c|c|c|c|}
\hline 樹木の番号 & 1 & 2 & 3 & \\
\hline \multirow{2}{*}{$\begin{array}{l}\text { 樹木の位置(メッシュ } \\
\text { 番号) }\end{array}$} & 3 & 7 & 12 & \\
\hline & 5 & 6 & 7 & 8 \\
\hline$\Longrightarrow$ (続き) & 13 & 15 & 17 & 23 \\
\hline
\end{tabular}

図 5 染色体の記述

に対して選択、交叉、突然変異などのオペレートを行い、それぞ れの適合度を計算する。挆査した個体の全てのうち、適合度が最 も高い個体は最適個体となる。

本研究はより効率的な島モデル遺伝的アルゴリズム (Multi-island Genetic Algorithm）文10)を用いた。図 4 に島モデルの 概念を示す。島モデル遺伝的アルゴリズム手法は並列分散（多点 同時探索型）の最適化手法である。その特徴は 1 つの世代での個 個体群を複数の島（sub-population）に分割し、各島で独立に遺伝 的操作を行い。各島の間で移住（migration）之呼ばれる個体情報 の交換を定期的に発生させる。今回の解析では、島の個数は 6 個、 各島での一世代の個体数は 10 個、一世代の個体数の合計は $6 \times 10$ $=60$ 個、世代数は 12 に設定した。探查の過程で解析された全個 体数は $60 \times 12=720$ 個となる。

図 5 に染色体の記述方法を示す。今回の樹木の配置問題は 2 次元格子平面に樹木配置できる 26 セルのうちの、どの 8 セルに樹 木を配置するかということを決定する問題とした。1 つの樹木を 
「ユニット」とし、それぞれに「樹木番号」を与える。この樹木 の並びに対して、それぞれの廚木を配置される位置（図 5 に定義 したメッシュ番号）の情報を与えたものを今回の GA で用いた染 色体とする。通常染色体は 2 進表記であり、遺伝子座には 0 か 1 が入るが、本研究では、染色体は 1 ～26で定義したメッシュ番号 を 2 進表記に変更し、対応的な遺伝子座に書き込みするという操 作によって設定した。

表 1 に本研究で利用した GA のパラメータを示す。本研究に おける、GA の操作の手順は具体的には下記のように行った。ま ず初期値として、ランダムに初期集団（第 1 世代）の各個体（60 個）を生成する。次に、放射・対流連成解析によりそれぞれ個体 の適合度を算出する。各島の 10 個の個体のうち、適合度が上位 4 位の個体を選択し、この 4 つ個体に対してランダムに単純交叉 （Simple crossover、交叉率 100\%)、あるいはランダムに突然変異 （Normal mutation、突然変異率 2\%）などのオペレータを行い、 次の世代の子供（個体）を 10 個体生み出す。そして更に同じオぺ レートを絽り返す。また、島モデル GA では、2 世代ごと（移住 間隔 2 ）で図 4 に示すのように、各島間において移住という個体 の交換を行う。移住先の島はランダムに決定し、各島の半分の個 体（移住率 0.5）を交換させる。このような移住を 2 世代ごと 6 回繰り返し、合計 12 世代の最適探査を行う。

また、本研究で利用した交叉は 1 点交叉であり、交叉や突然 変異により遺伝子座（樹木の位置）が重なる場合にはその解を除 外している注2)。

\section{6 解析ケース}

表 2 に解析ケースを示す。注目される領域の異なりにより最 適探查にどのような影響を与えるかを検討するために、下記の 3 つケースの解析を行った：(1) case0：基本ケース、樹木を配置し ないケース。(2) case1：解析領域全体を注目対象とする。即ち、 解析領域の高さ $1.5 \mathrm{~m}$ における各ポイント SET*の合計の検討を行 う。(3) case2 : 人間活動領域を注目対象とする。即ち、道路部に おける SET*の合計の検討を行う。

\section{7 解析手順}

本研究では図 2 に示す解析手順を用いた。第 1 段階探査では CFD 解析は粗メッシュの渦粘性係数を固定した解析で行った。この 段階では全解析空間において屋外の気温之相対湿度の空間分布を 一様に仮定した。全て解候補のうちに、最適評価値（適合度）の上

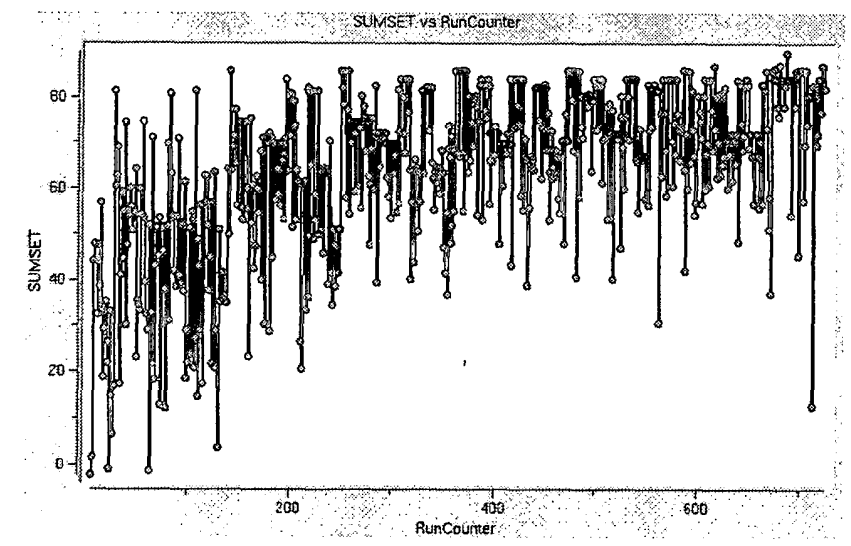

図 6 case1 第 $\mathbb{1}$ 段階探植過程
位 10 位個体を第 2 段階の最適探査の候補とする。また、2 つの段 階において基本ケース（樹木なし）の SET*をそれぞれに算出し、 それぞれの段階の最適評価基準值とする。

\section{4. 解析結果と考察}

\section{1 第 $\mathbb{1}$ 段階探查}

図 6、7 case1 と case2 の第 1 段階における GA による最適 探査過程を示す。横軸は最適探查のステップ数（RunCounter）で あり、縦軸は評価関数（SUMSET）である。最適探査の進行に伴 う、個体の適合度が向上となる傾向がみられ、GA による最適探 查は効率的なツールであると考えられる。また、図 8、9に case1

表 1 GA のパラメータ

\begin{tabular}{|ll|c|}
\hline 島のサイズ & （Size of Sub-Population） & 10 \\
\hline 島の数 & (Number of Island) & 6 \\
\hline 一世代の個体数 & (Fopulation size) & $60(10 \times 6)$ \\
\hline 世代数 & (Number of Generation) & 12 \\
\hline 全個体数 & (Total individual size) & $720(60 \times 12)$ \\
\hline 移住率 & (Rate of Migration) & 0.5 \\
\hline 移住間隔 & (Interval of Migration) & 2 \\
\hline トーナメント率 & (Rate of tournament) & 0.4 \\
\hline 交叉率 & (Rate of crossover) & 1.0 \\
\hline 突然変異率 & (rate of mutation) & 0.02 \\
\hline
\end{tabular}

表 2 : 解析ケース

\begin{tabular}{|c|l|}
\hline case0 & 基本ケース（樹木を配置しない) \\
\hline case1 & $\begin{array}{l}\text { 領域全体を注目される(解析領域高さ } 1.5 \mathrm{~m} \text { にお } \\
\text { ける水平面) }\end{array}$ \\
\hline case2 & $\begin{array}{l}\text { 人間活動領域を注目される（道路部で高さ } 1.5 \mathrm{~m} \\
\text { における水平面） }\end{array}$ \\
\hline
\end{tabular}

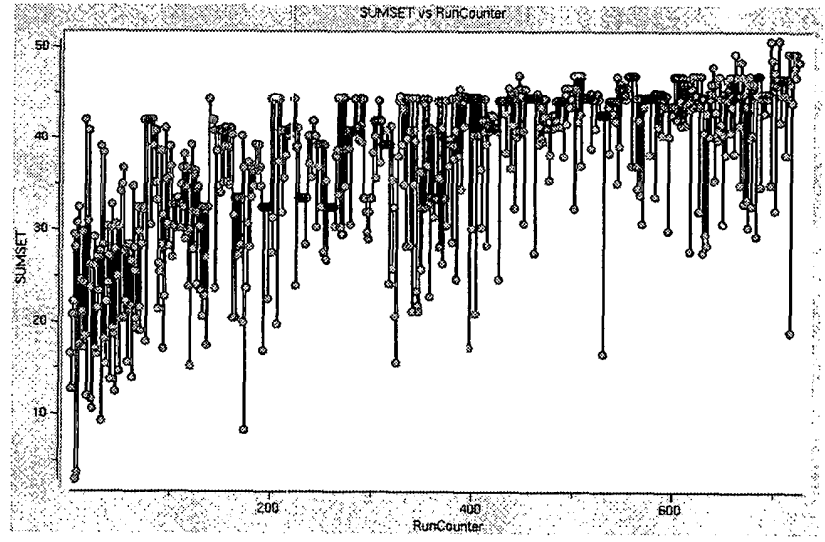

図 7 case2 第 1 段階深査過程 


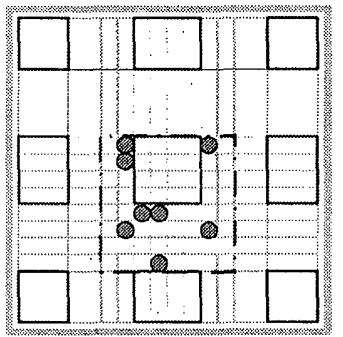

第 1 位 wind

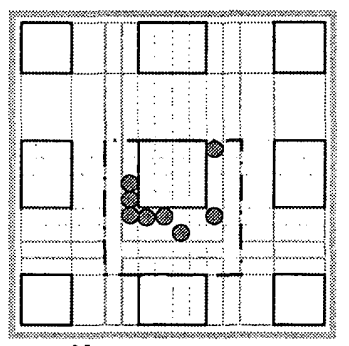

子 $^{\mathrm{N}}$ 第 1 位

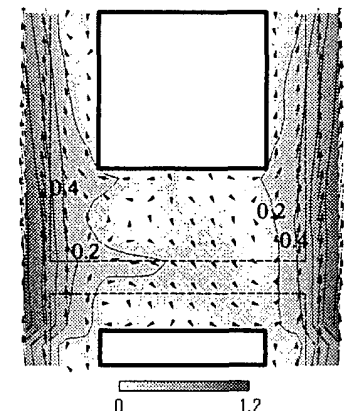

(1) 風速ベクトルとスカラ

一値の水平分布 $(0.39 \mathrm{~m} / \mathrm{s})$

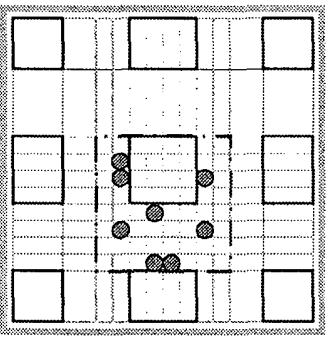

第 2 位

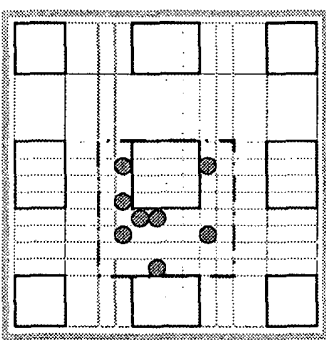

第 3 位

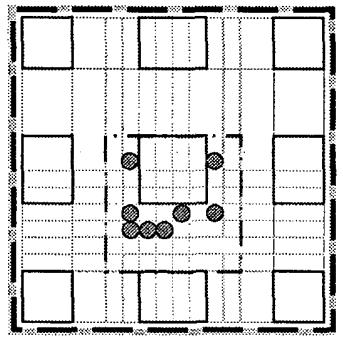

第 4 位

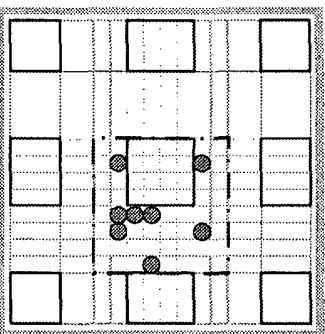

第 5 位

図 8 case1 GAによる第 1 段階の最適探查結果（上位 5 位まで）

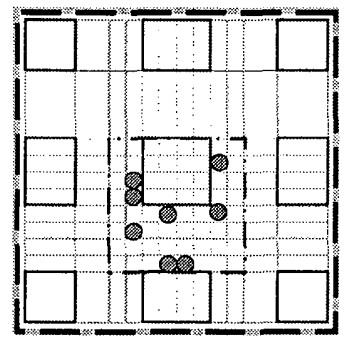

第 2 位

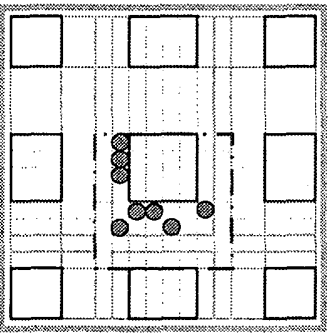

第 3 位

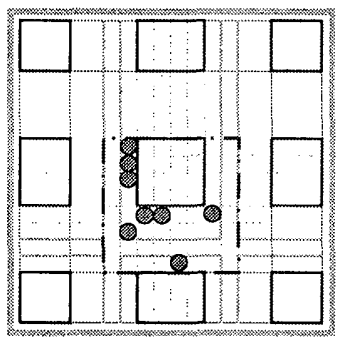

第 4 位

図 9 case2 GA による第 1 段階の最適探査結果（上位 5 位まで）

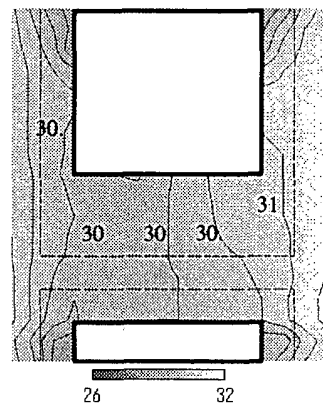

(2) 気温の水平分布 $\left(29.6^{\circ} \mathrm{C}\right)$

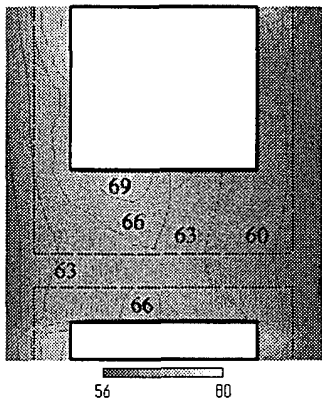

(3) 相対湿度の水平分布 $(62.9 \%)$

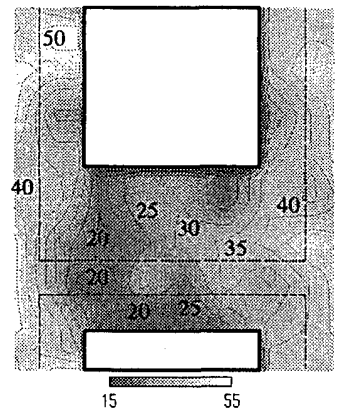

(4) MRT の水平分布 $\left(35.9^{\circ} \mathrm{C}\right)$

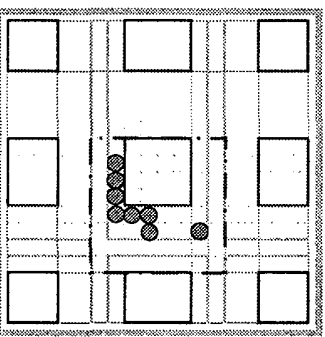

第 5 位

図 10 case1 最適設計の温熱環境 （括弧内の値はそれぞれの面内平均值）(高さ $1.5 \mathrm{~m}$ ）

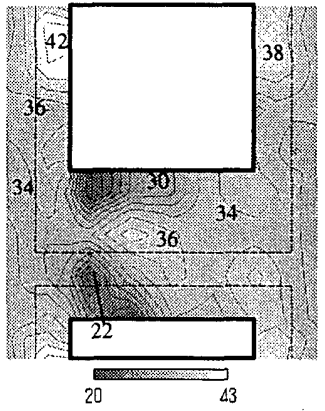

(5) SET*の水平分布 楽

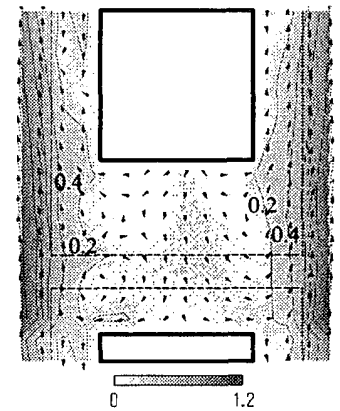

(1) 風速ベクトルとスカラ

一値の水平分布 $(0.35 \mathrm{~m} / \mathrm{s})$

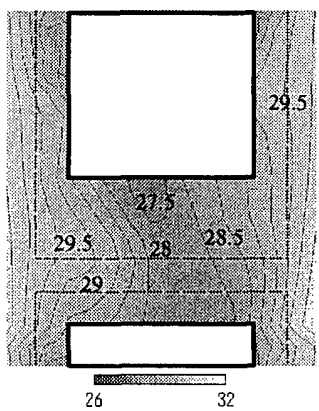

(2) 気温の水平分布 $\left(29.1^{\circ} \mathrm{C}\right)$

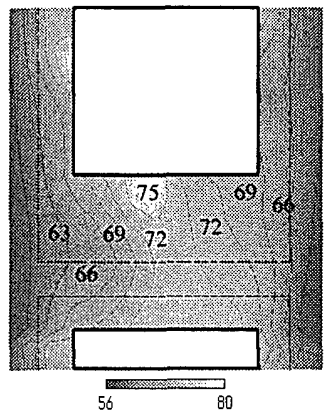

(3) 相対湿度の水平分布 $(65.9 \%)$

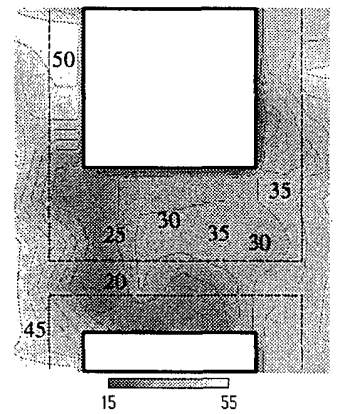

(4) MRT の水平分布

$\left(36.4^{\circ} \mathrm{C}\right)$

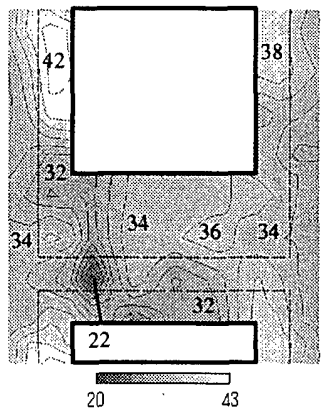

(5) SET*の水平分布

図 11 case2 最適設計の温熱㺺境 （括弧内の值はそれぞれの面内平均值）（高さ $1.5 \mathrm{~m}$ ）

と case2 において第 1 段階の最適探查結果（上位 5 位まで）を示 す。東京の 7 月 23 日午後 3 時の太陽方位は西南西であり、建物の 西側と南側の外壁面の表面温度は高温となる。両ケースとも MRT を低減するため、樹木が建物の西側と南側に配置される傾向が見 られる。解析領域全体を注目する casel では、樹木は領域におけ る平均的に配置されるが、これと異なり、人間活動領域を注目す
る case2 では、樹木が主に道路際を中心に配置されることが示さ れる。

\section{2 第 2 段階探査}

case1 と case2 における第 1 段階探查で選ばれたそれぞれ 10 個体について第 2 段階探查を行う。詳細的な放射・対流・湿気輸 送連成解析により選ばれた最適設計（最適個休）は図 8、9 に点線 
で囲まれた樹木配置のパタンで示される。図 $10 、 11$ case1 と case2 の最適設計の温熱環境を示す。case1 は case2 に比べ、面内 平均值において、casel は case2 より $0.5^{\circ} \mathrm{C}$ 程度の気温が增加する が、気温の上舁に伴い case1 は case2 より $3 \%$ 程度の相対湿度が低 くなる。また、case1 の風速スカラー值は case 2 より $0.04 \mathrm{~m} / \mathrm{s}$ 程度 増加し、case2 より $0.5^{\circ} \mathrm{C}$ 程度の MRT が低下となった。表 3 に最 適個体の全領域と道路部における高さ $1.5 \mathrm{~m}$ の平均 $\mathrm{SET} *$ の值を示 す。基本ケースと比べ、 case1 と case2 では SET*が低下し、樹木 の配置による屋外温熱環境緩和効果が認められるが、casel では全 領域の平均 SET*は case2 に比べ若干低下するが、道路部における SET*が高くなる。最適評価の目標領域の異なりにより最適探查の 結果に大きな影響を与えることが分かる。

MRT を低減するため、最適解では樹木が全て建物の南側と西 側に配置されると想定したが、最適個体では両ケースとも建物の 東側と北側に配置された樹木（case1 の 25 番、case2 の 3,4,25 番) もあった。この原因としては以下 2 点と考えられる。ここで、例 として case2の第3位のような樹木を配置する個体と比べ、(1)case1 では、評価関数（適合度）の注目領域は全解析領域であり、case1 の第 1 探查での最適個体（第 4 位の個体）では、領域全体的に MRTがやや高くなるが、流れ場から見ると、上記の個体では、樹 木が敷地の西南角に集中しているため、建物キャニオン空間にお ける循環流を生じ、その場所での風速が大きくなった。また、メ ッシュ番号 25 の樹木は直接、直達日射を遮蔽しているわけではな いが、建物壁面からの日射反射や照り通しによる長波放射を遮蔽 するため、その周辺の MRT を低下させる効果があった。このた め、第 4 位の個体の SET*が低下し、最適個体となった。(2)case2 では、評価関数（適合度）の注目領域は道路部である。解析時刻 の太陽方位は西南西であるので、case2 の第 1 探査での第 2 位のよ うに樹木が道路の西側と南側に配置されると、道路部は日陰にな らない。樹木の配置による日射遮蔽効果がないために、この配置 については若干奇異な結果に思えるかもしれない。しかしながら、 上記の個体では、メッシュ番号 3、4、25 の樹木は隣の建物壁面か らの日射反射と照り通しによる長波放射を遮蔽するため、第 1 探 査での第 3 位個体と比べ、道路部の MRT は逆に低くなる。この ために、道路部を注目する case2 では、第 2 位個体が最適設計と なったと考えられる。

尚、今回の解析で示された結果により、本最適設計手法は設 計者の設計段階の参考として効果があると考えられる。

\section{5. まとめ}

（1）屋外温熱環境設計ため、GA を利用した樹木の最適配置に 関する最適設計手法の開発を行った。

（2）全屋外空間と歩行者空間といった注目する領域の違う 2 つケースを解析し、注目する領域の違いが最適探查結果に影響を 与えることが分かった。

（3）基本ケースと比べ、今回の最適探査で得られた結果は case 1 、 case2 とも樹木による屋外温熱環境緩和効果が認められる。また、 case1 に対して、case2 では全解析領域における SET*の平均值が $0.4^{\circ} \mathrm{C}$ 程度高くなったが、道路部における SET*の平均值が逆に $0.2^{\circ} \mathrm{C}$ 程度低下した。このように注目した領域に応じて、その部分
表 3 高さ $1.5 \mathrm{~m}$ の平均 $\mathrm{SET}{ }^{*}\left[{ }^{\circ} \mathrm{C}\right]$

\begin{tabular}{|l|l|l|l|}
\hline & Case 0 & Case1 & Case2 \\
\hline 全領域 & 39.59 & 34.32 & 34.71 \\
\hline 道路部 & 40.25 & 34.28 & 34.10 \\
\hline
\end{tabular}

の温熱環境の最適化が達成され、本提案手法の妥当性が示唆され たと考えられる。

（4）本研究の解析結果においては、両ケースとも最適個体に対 する、不良個体の $\mathrm{SET}^{*}$ の平均值は $2^{\circ} \mathrm{C}$ 程度を上昇し、樹木配置の 位置の異なりにより幄外温熱環境に大きな影響を与え、樹木の最 適配置に関する検討浨必要ということが分かった。また、近年、 ヒートアイランドの進行に対する環境工学分野だけではなく、都 市計画・建築計画分野においても多くの研究を行われている。こ のような背景から、奏際の設計に対して、樹木の最適配置に関す る解析結果は設計者の設計段階の参考として実用の効果があると 考えられる。

注 1）本報では屋外温熱環境に対する樹木の最適配置手法のプロトタイプ を開発することが主目的である。一方、解析対象や条件に関してはモテル として極めて簡素に設定している。従って、今回の解析結果をもって、沉 用的な設計指針が得られたと考えることできない。あくまで手法の開発と それによって何か可能かということを提示していると理解されたい。また、 植樹は冒頭に述べたように実際には温熱罢境のみならず、様々な要因を考 慮して設計される。今後はこの様々な要因や設計目標を統合的に取り扱う 最適設計手法について検討を進めて行く予定である。

注 2）本研究では、遗伝子型において各の遗伝子座の値が重なる場合があ るため本研究では、下記の方法により対応した。各個体の評価関数（適合 度）の算出は遗伝子の遗伝子型（genotype）から表現型（phenotype）に翻 訳した後に行われるため、遺伝子の遗伝子型から表現型に翻訳する時の方 法を例として、下記の図に示す場合に関し説明する。まず、染色体におい て記載される遺伝子座の值（樹木の位置）を大きい方から小さい方への順 番に並べる。次に、樹木を配置するメッシュ番号の列の内に第 1 番目の樹 木 (T1') 数値 (10) に刘応する順番のメッシュ番号を取って、掼伝子の表 現型における第 1 番目の樹木の位置を $\mathrm{T} 1$ （10）とする。また、1 つメッシ ユで 1 つ樹木しか配置しないということで、第 1 番目の樹木位置を与えた

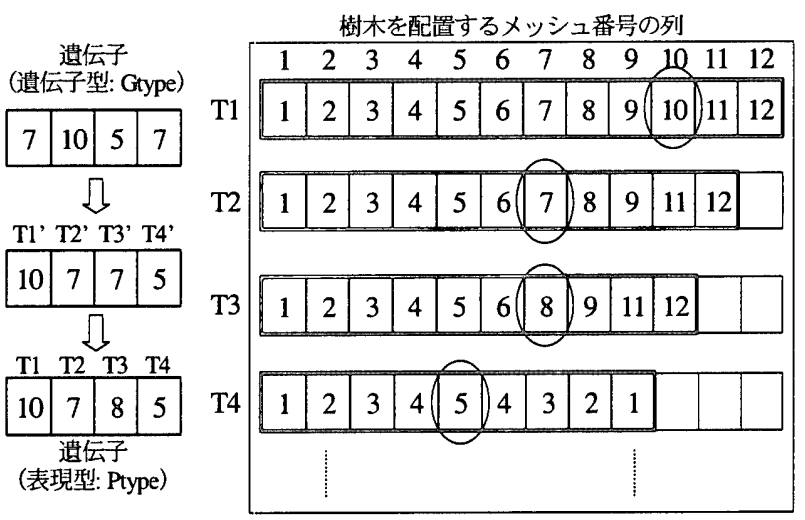

図 遺伝子型（genotype）から表現型（phenotype）への細訳方法 
後、そのメッシュ番号（10）をメッシュ番号の列の内から削除する。つま り、第 2 番目の樹木が配置できるメッシュ数が 11 となる。但し、メッシュ 番号の列の順番について 10 を消すと、順番 10 の位置でメッシュ番号は 11 となり、順番 11 の位置でメッシュ番号は 12 となる。その後、第 2 番目の 樹木対する、メッシュ番号の列に $\mathrm{T} 2{ }^{\prime}$ の数值（7）に対応する順番のメッ シュ番号を取って、遺伝子の表現型における第 2 番目の樹木の位置を $\mathrm{T} 2(7)$ とする。更に、第 2 番目の樹木のメッシュ番号（7）をメッシュ番号の列の 中から消す。順番 7 の位置でのメッシュ番号は 8 となり、順番 8 の位圈で メッシュ番号は 9 となる。第 3 番目の樹木に対して、メッシュ番号の列に T3’ の数値（7）に対応する順番のメッシュ番号（8）を取って、遺伝子の 表現型における第 3 番目の樹木の位置を T3（8）とする。同じ方法で第 4 番目の樹木の位置（T4）は 5 となる。以上のような操作を繰り返すことに より表現型における遺伝子座の値の重なりを除外した。遗伝子座の值を大 きい方から順番に並べたのはメッシュ番号が変化することによる䫅雑さを 避けるためである。

\section{[参考文献]}

（1）萩島理、片山忠久、林徹夫、谷本潤、樹木の放射温度分布に関する実 測、街路樹のある街路の温熱罱境予測 その1、日本建築学会計画系 論文集、第.516号、79-85 1999.2

（2）萩島理、片山忠久、林徽夫、谷本潤、数値計算による街路樹の暑熱緩 和効果の評価，街路樹のある街路の温熱環境予測その2、日本建築学
会計画系論文集 第 525 号、83-90、1999.11

(3) 吉田伸治、大岡龍三、持田灯、富永䄙秀、村上周三、樹木モデルを組 み込んだ対流・放射・湿気輸送連成解析による樹木の屋外温熱環境緩 和効果の検討、日本建築学会計画系論文集 第 536 号、87-94, 2000.10.

（4）三井和男、富田敬一、登坂宣好、满造形態解析における遺伝的アルゴ リズムの応用、日本建築学会学術講演梗概集（構造 1）、 1211-1212,1994;

(5) 岡本英樹、服部岑生、非線形評価関数を含む最適配置へのニューラル ネットワークの適用、日本建築学会学術講演梗概集（建築計画 1）、 773-774,1993 ;

（6）青木義次、村岡直人、邁伝的アルゴリズムを用いた地域施設配置手法、 日本建築学会計画系論文集、第 484 号、129-135, 1996 ;

（7）金泰延、加藤信介、村上周三、遭伝的アルゴリズムと CFD を組み込 んだ室内温熱澴境の 2 段階型最適設計手法の開発、空気調和・衛生工 学会学術講演会講演論文集、69-72, 2001；

（8）北野宏明編、遭伝的アルゴリズム 1、産業図書株式会社、1993：

(9) A.P.Gagge, J.A.J. Stolwijk, Y. Nishi, A Standard Predictive index of human respons to the thermal environment, AHSRAE Transactions, 92(1), 709-731, 1986 。

(10) Reiko Tanese, Distributed genetic algorithms, Proc.3rd ICGA, pp. 434-439, 1989 